\title{
University biotech patenting 2013
}

\section{Brady Huggett \& Kathryn Paisner}

The University of California system again tops our list of the most active academic centers for biotech patenting over the past five years (Table 1), followed by the Wisconsin Alumni Research Foundation and, lower down, the Pasteur Institute. Last year, the California system also recorded the most patents issued from the United States and European Union combined. Overall, the number of US biotech patents awarded in 2013 skyrocketed (Fig. 1); this jump is attributed to a greater number of biotech patent examiners at the US Patent and Trademark Office, which has allowed the office to work through a backlog of submissions brought on by increased university technology transfer efforts across the United States.

\section{COMPETING FINANCIAL INTERESTS}

The authors declare competing financial interests: details are available in the online version of the paper (doi:10.1038/nbt.2918).

Table 1 Top academic centers ranked by number of biotech patents, 2009-2013

\begin{tabular}{|c|c|c|c|c|c|c|}
\hline University & Total & Yearly average & US total & EU total & 2013 & 2013 \\
\hline University of California system & 504 & 100.8 & 432 & 72 & 107 & 19 \\
\hline Wisconsin Alumni Research Foundation & 278 & 55.6 & 244 & 34 & 45 & 2 \\
\hline Stanford University & 242 & 48.4 & 209 & 33 & 41 & 7 \\
\hline University of Pennsylvania & 203 & 40.6 & 160 & 43 & 41 & 8 \\
\hline Duke University & 201 & 40.2 & 186 & 15 & 46 & 2 \\
\hline Pasteur Institute & 195 & 39 & 115 & 80 & 24 & 12 \\
\hline University of Massachusetts & 132 & 26.4 & 116 & 16 & 28 & 2 \\
\hline Massachusetts Institute of Technology & 125 & 25 & 115 & 10 & 31 & 1 \\
\hline University of Michigan & 120 & 24 & 107 & 13 & 23 & 2 \\
\hline New York University & 110 & 22 & 98 & 12 & 20 & 3 \\
\hline University of Illinois system & 104 & 20.8 & 94 & 10 & 20 & 3 \\
\hline Harvard University & 102 & 20.4 & 85 & 17 & 21 & 3 \\
\hline University of Southern California & 83 & 16.6 & 68 & 15 & 16 & 3 \\
\hline University of Washington & 79 & 15.8 & 67 & 12 & 15 & 2 \\
\hline University of Florida & 77 & 15.4 & 64 & 13 & 20 & 1 \\
\hline Yale University & 77 & 15.4 & 58 & 19 & 11 & 5 \\
\hline Rockefeller University & 76 & 15.2 & 64 & 12 & 16 & 4 \\
\hline Yissum (Hebrew University) & 61 & 12.2 & 41 & 20 & 3 & 2 \\
\hline University of lowa & 58 & 11.6 & 50 & 8 & 6 & 2 \\
\hline Ramot at Tel Aviv University & 58 & 11.6 & 37 & 21 & 13 & 5 \\
\hline Ohio State University & 37 & 7.4 & 37 & 0 & 36 & 0 \\
\hline Institut National de la Santé et de la Recherche Médicale (INSERM) & 33 & 6.6 & 32 & 1 & 28 & 1 \\
\hline Cornell University & 29 & 5.8 & 22 & 7 & 8 & 3 \\
\hline
\end{tabular}

Source: IP Checkups Inc.

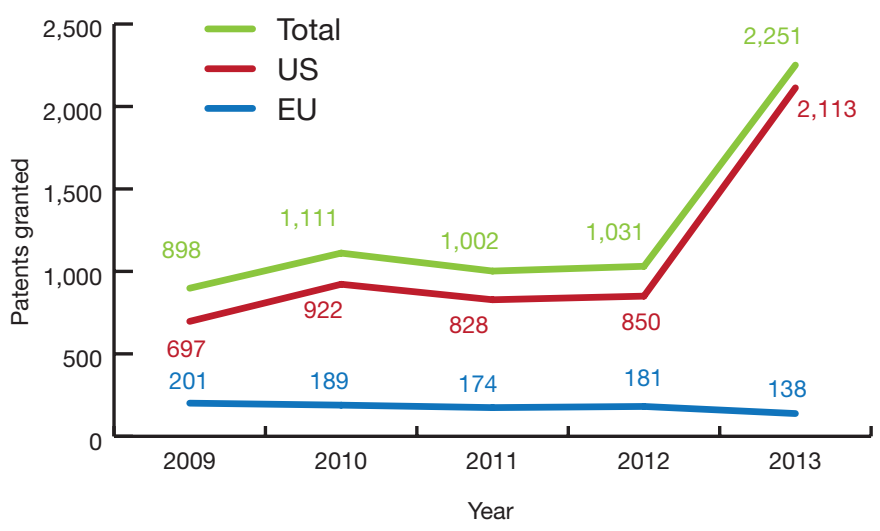

Figure 1 Biotech patent trends, 2009-2013. Source: IP Checkups Inc.

\section{First Rounders Podcast: Leroy Hood}

Lee Hood was one of the pioneers involved in the Human Genome Project as well as a cofounder of Applied BioSystems and numerous other biotech startups over the past three decades. In 2000, he cofounded the Institute for Systems Biology (ISB) in Seattle, where as president he is currently leading research with a view to moving toward precision medicine. Nature Biotechnology spoke to Hood about his long association with the California Institute of Technology, the P4 pilot project at ISB and playing football in the Rose Bowl. http://www. nature.com/nbt/podcast/index.html.

Brady Huggett is business editor at Nature Biotechnology.

Kathryn Paisner is director of research and analytics at IP Checkups Inc., Berkeley, California, USA.e-mail: kpaisner@ipcheckups.com. 